\title{
Title: Defining Government Performance Expectations: Insights from the US and UK Financial Bailout Proposals Workgroup II: Performance in the Public Sector
}

ARTICLE · JANUARY 2009

\section{READS}

11

1 AUTHOR:

\section{Simona Zambelli}

University of Bologna

11 PUBLICATIONS 29 CITATIONS

SEE PROFILE 
Title: Defining Government Performance Expectations: Insights from the US and UK Financial Bailout Proposals

Workgroup II: Performance in the Public Sector

Authors: Eric A. Scorsone, Ph.D.

Co-Chair, State and Local Government Program

Department of Agricultural, Resource and Food Economics

Michigan State University

(517) 353-9460

scorsone@msu.edu

\&

Simona Zambelli, Ph.D.

Assistant Professor

Department of Finance

University of Bologna at Forli

Abstract: The economic and financial crisis of 2008 has raised some particularly challenging issues regarding assessing the performance of proposed financial institution bailout solutions. The need for quick action to avoid financial disaster often precluded a full airing of the possible advantages and disadvantages associated with the accountability and performance indicator mechanisms put in place. Now, a vigorous debate is occurring over performance indicators related to the effectiveness, efficiency and equity aspects of the solutions that have been implemented both in the U.S. and Europe. The United States major bailout proposal was the Troubled Assets Relief Program (TARP) overseen by the Office of Financial Stability in the US Department of Treasury which has taken major ownership positions in US banks. The British bailout plan called the Bank Recapitalisation Scheme (BRS) is being directed by HM Treasury and the United Kingdom Financial institutions, Corp. which has also taken equity positions in major UK banks. These similarities and differences form the backdrop for the empirical case studies. The particular nature of these government programs make them ideal candidates for an extreme type case analysis in the characterizing the fight over defining performance. Not surprisingly, a host of academics, private financial institutions, government agencies and even intergovernmental governing bodies such as the IMF are airing their respective performance definitions. The competition between these bodies will serve as the empirical basis for assessing the arguments and motivations over how to define performance in the context of the bank bailouts. These case studies will be analyzed in the performance regime and competing values conceptual frameworks as initially brought together in 
Talbot $(2008)^{1}$. The performance regime frame will help assess the institutional forces who are attempting to exert influence over indicators. The competing values frame advances the notion that there are four major types of models by which social relationships are constructed and the form through the regime influences impact indicators and performance definitions. The major new contribution presented here will be in using these case studies to define the types of variables and factors that drive different types of private and public agents in constructing the definition of performance as well as advancing this combination of the performance regime and competing values framework. It is felt that these financial bailouts provide a rich set of data upon which new insights and the advancement of knowledge can be constructed. The United States and United Kingdom models represent important cases where large scale financial bailouts have occurred in two countries that have similar business cultures and yet there remain important differences in their approaches.

\footnotetext{
${ }^{1}$ Talbot, Colin . “Introduction - The Rise of the Performance Measurement Movement”. July 2, 2008.
} 


\section{Introduction}

Most western national governments now have formal systems of performance measurement and management. These systems are intended to serve as one basis for guiding and steering managers, having a role in the budget allocation process and allowing a government to set national priorities and evaluate success and failure. In truth, these systems serve these ends in often very imperfect ways. Regardless, they have a certain legitimacy by the very existence and the time allocated to undertaking such ventures. While there has been significant research and examination of the status and comparison of such systems (for example, Halligan and Bouckaert, 2008), there has been less emphasis's on examining comparison in how these systems change over time.

Performance indicators and entire performance management systems are dynamic in both structure and content over time. Witness, the US system as it evolved from the Government Performance and Results Act under President Clinton to the Performance Assessment Rating Tool under President Bush the likely further reinvention by President Obama. There is a gap in our knowledge base on how and why such systems change over time. Particularly relevant is a side by side comparison in changes in performance management systems over time. This paper seeks to make an advance in the literature by examining the impact of an extreme event or shock on an existing performance indicator system and attempts to define and redefine performance indicators in the UK and the US.

Given the scale and scope of national governments, it is sensible to focus on one particular aspect of government to undertake a comparative analysis and attempt to control to some extent for extraneous factors. The current global financial crisis provides an interesting setting for examining changes in performance indicators. Just as a physician learns from extreme patient cases, so public administrations scholars can learn from extreme cases and the impact they have on performance indicator systems. The test subjects are the United States and United Kingdom national treasuries and financial regulatory systems. In both countries, the Treasury department has formal performance management systems in place with well developed performance indicators. At least some extraneous factors, such as the type of banking system, type of economy and other sociodemographic factors, have common ground as compared with other possible test subjects. Finally, both countries have been subjected to a severe financial crisis due to the unwinding of mortgage backed security assets. These similarities and controlled differences make for an interesting case study analysis. Using these examples, the goal is to advance the literature on understanding dynamics in performance indicators systems. 


\section{Setting the stage: Previous Performance Management Frameworks}

There have been several different approaches to understanding the structure, adoption and implementation of performance management systems in the public sector. Bouckaert (1993) and Bouckaert and Halligan (2008) identify three major criteria that performance management systems must be compared against including validity, legitimacy and functionality. Validity refers to a characteristic of performance measurement systems that indicates the measures do capture the behavior or results that are actually occurring in a government system. Using Bouckaert's words, "a valid measure is one that is sound, cogent, convincing, and telling" (Bouckaert, 1993: 31). Legitimacy refers to a characteristic of a performance measurement system as to whether it is trusted or believed in by agents, or stakeholders that could include internal groups such as employees or external groups such as citizens or business associations. Functionality is the third characteristic that can be used as a criterion to evaluate performance measurement systems. This characteristic refers to whether the organization receives or infers benefits from the implementation and use of performance measures. This framework is more of a normative or ideal type system rather than an explanatory framework. It does present one of the most comprehensive frameworks for assessing public performance management systems.

Moynihan (2008) is another author who presents a framework for understanding the adoption and implementation of performance management reforms. He uses an interactive dialogue model to understand the phenomena. The framework, unlike the dominant rational economics type approach, sees information being used by actors as a part of a social forum in which public policy decisions are being deliberated and carried out. In this context, information has use through the social forum its impact on decision making is neither rational nor linear has traditional economic type approaches to information use would be expected to favor. In economics, information is often viewed as a commodity with a price which rational actors will invest in up to the point that net benefits are maximized.

Information is separate from the actors in this model and exists as its own entity independent of the actors. The interactive dialogue model assumes that information is inherently a social phenomenon which is created and shaped by actors via their interaction. In this context, impact and use must be determined in a manner far different from the rational economics approach.

A different approach to performance measurement and management has been introduced by Colin Talbot and others known as the performance regime (Talbot et al, 2005). In this context, the regime is the set of actors who share the definitions and standards used in a performance management system. Again, the emphasis is on the institutional or social nature of performance information. These 
ideas remind us of the larger framework within which performance indicator systems are situated and influenced.

Pollitt reminds us that policy and management take place over time and this dimension has been neglected by research in the past (Pollitt, 2008). He presents several models that incorporate time into policy and management including traditional history, path dependency, cycles, sociological and organizational approaches. The recent analysis seeks to incorporate time as a dimension in understanding the evolving nature of the performance management systems at the UK and US treasuries. A baseline question is whether the financial crisis will shape both the short and long term structure of these systems. One possibility is that the crisis will only be a temporary blip on an otherwise stable performance system. Another possibility is that the performance system will experience a tectonic shift due to the crisis with major changes to indicators, goals and its entire structure.

Pollitt (2008) explores the "logic of escalation" in performance management systems. He examines changes in performance measurement indicators in the health systems of the UK and the Netherlands. He finds that over time authorities continue to expand the number and complexity of indicators measured and managed. This is due to the continual finding of gaps in the knowledge base and further that old indicators do not get replaced but rather are added to new indicators. However, he also finds a cycle where occasional attempts are made to create indexes are summative performance indicators as the system becomes too complex and then the cycle begins again.

Pollitt et al. (2007) also describe the different trajectories that "performance regimes" exhibit. They examine performance systems in the UK and Netherlands over the past thirty years. Again, they find that the number and complexity of indicators expands over time. Further, in turn, the complexity of the indictors makes it difficult for politicians and citizens to use the system for decision making. In essence, the system becomes captured by experts. This cycle is evident in both countries and reinforces findings from Pollitt's other work.

An early paper by Pollitt (1989) explored performance indicators in the long term. In this case, he examined the UK National health service in the 1980's. Again, he found that over time politician's interest in the system waned and middle managers were better able to manipulate the system. Even in this early work, Pollitt finds a system where performance indicators continue to increase in number and complexity, driven by experts, and that the usability of such a system by citizens and politicians declines 
over time. These findings drive the research question posed in this paper where we explore the initial impact of global financial crisis on performance indicators as expressed by national treasuries and associated financial regulators.

This paper attempts to build on Christopher Pollit's work to understand how performance management system systems are subject to pressures for change and redefinition over time. As stated previously, the setting is the bank bailouts and the financial crisis of 2008 and 2009 in the UK and US. Bouckaert and Halligan's criteria will also be used to provide some assessment of both the current performance management systems in the two countries as well as proposed changes to such systems. These methodological tools will be used to advance our understanding of how performance managements are debated and redefined over time.

\section{Background to a Crisis: Toxic Assets and Bank Bailouts}

In October 2008, both the U.S. and U.K. governments moved into place massive bank bailout legislation and implementation. The Emergency Economic Stabilization Act of 2008 (EESA), the US bank bailout plan, is one of the most important laws in modern American economic history. The UK government using existing authority moved also to undertake a massive bank bailout scheme known as the Bank Recapitalisation Scheme (BSR). The main purpose of these efforts was to stabilize what was considered a failing financial system due to the implosion of the mortgage asset-backed security system. The genesis of these bank bailouts originates from the subprime mortgage, so called toxic assets, crisis that finally cumulated in the failure and insolvency facing Lehman Brothers Investment firm and the AIG insurance corporation in the middle of September 2008. While there were warning signs in the latter part of 2007 and the early part of 2008 of serious problems in the financial system, it was these individual firm crises that led to the passage of this landmark legislation in both countries. 


\section{U.S. Bank Bailout Law}

The proposed law in the United States was originally introduced to Congress by U.S. Treasury Secretary Henry Paulson on September 21, 2008. As conceived, the plan asked Congress for access to $\$ 700$ billion to purchase troubled assets from banks who were in serve danger of failing due to the collapsing asset backed security market. As these assets fell in value, banks were forced to come up with further capital to cover losses. These losses were draining capital from the financial system leading to major restriction of credit flow against all firms including those who were high quality borrowers. This contagion threatened a shutdown of the entire U.S. financial system. The plan, only three pages in length, stated that the decisions taken by Treasury were not to be reviewable by any court or administrative agency thus providing near absolute immunity from any traditional accountability mechanisms. The rationale for the provision was that absolute immunity was necessary for the program to work and investors to have confidence in such a plan.

The plan as introduced was met by intense criticism in some quarters and support in others. Many economists felt that the asset purchases, the heart of the proposal, would not work. Some commentators, such as Paul Krugman of the New York Times, felt that the government should buy stakes directly in the banks rather than purchasing assets (Krugman, 2008). The plan was attacked by both liberal and conservative economists. Liberal economists attacked the plan because it was seen as a subsidy to rich corporations with very little assistance to homeowners and conservative economists because it threatened to involve the government too heavily in the affairs of private companies.

The U.S. Congress initially balked at the plans provisions and voted the original version down which immediately led to the biggest stock market selloff in history. After several changes to the law, it passed with several important new provisions. The major portion of the bill was the so called Troubled Assets Relief Program (TARP). The TARP was originally designed to be a program where the government would purchase "toxic" asset backed security assets from the financial institutions in order to restore stability and liquidity to the credit system. The Office of the Financial Stability (OFS) was established in the U.S. Department of Treasury to implement this program. The TARP was funded to the tune of $\$ 700$ billion. Of this amount, $\$ 350$ billion was immediately available; the executive branch had to return to Congress to ask for the second $\$ 350$ billion.

The revised plan included new language on the goals of the program. As envisioned, the plan was to achieve four goals including: 1) protects asset values, 2) preserves home ownership, 3) maximize 
taxpayer return and 4) provide public accountability. It can be argued that some of these objectives can actually be in conflict with one another. For this current paper, the most important point is that congress explicitly enacted a public accountability goal in the legislation. Later in the legislation, Congress enacted several accountability mechanisms which will be discussed later. The placement of these accountability mechanisms in the law led to a major debate over the types of performance indicators that should be used and tracked to determine the policy's effectiveness.

The TARP plan, as passed by Congress, did contain important performance and accountability provisions. In fact, of its four main goals which included home ownership preservation and financial stability, public accountability was one of the four. As stated, the law explicitly provided for "provides public accountability for the exercise of such authority" (H.R. 1424, Section 2, 2008). Throughout the law, there are references to accountability particularly in regards to the oversight by the Government Accountability Office (GAO). In terms of accountability, Congress also created the Congressional Oversight Panel (COP) whose main function is to determine if the policy objectives of Congress are being carried out. There are three separate entities that have responsibility for overseeing the implementation of the TARP. These include the Government Accountability Office (GAO), a special inspector general (SIGTARP) and the Congressional Oversight Panel (COP). The SIGTARP lays out its responsibilities as: 1) promoting the transparency of how TARP funds are being disbursed and used, 2) promoting coordinated oversight of the funds in conjunction with GAO and COP and 3) detecting and investigating cases of fraud and abuse in the program. The SIGTARP appears to be playing the lead role in the detection and investigation of fraud relative to the other two overseers.

The Government Accountability Office (GAO) was widely mentioned throughout the Emergency Economic Stabilization Act. There were directions in the law to GAO including internal controls, compliance with applicable laws, characteristics and dispositions of assets, efficiency of the operation, efficacy of the contracting procedures, efforts to prevent and control conflict of interest and information on the types of transactions the TARP entered into. All of these areas were under the purview of the GAO.

In the law, another layer of oversight or accountability mechanism was created through the U.S. Comptroller General. This accountability body which was created was known as special inspector general of the TARP also known as the SIGTARP. The SIGTARP was specifically charged with reviewing specific transactions with financial institutions and all of the information surrounding those transactions. Here the emphasis, while again consisting of some overlap with the GAO, was targeted at criminal 
prosecution of any wrongdoing found in the implementation of the law. Thus, GAO had an auditing and accounting type role whereas SIGTARP had more of a law enforcement and investigation role. It was not determined in the law how the either GAO or SIGTARP should balance the four objectives as stated in the first part of the law were to be balanced or assessed relative to one another.

A third accountability mechanism was the Financial Stability Oversight Board. The goal of this board was to ensure that the funds were being allocated in fair and efficient manner. The Financial Stability Oversight Board membership includes the Chairman of the Federal Reserve, US Treasury Secretary, Director of the Federal housing Authority, chairman of the Securities and Exchange Commission and the Secretary of the US department of Housing and Urban Development. A second panel, directly reporting to congress, was established known as the Congressional Oversight Panel.

The Congressional Oversight Panel was also established in section 125 of the law as the fourth accountability mechanism. This panel was charged with a set of specific task different from the GAO. Under the law, the panel would issue regular reports to Congress regarding the impact of TARP purchases on the overall marketplace, impact on market transparency and the effectiveness on foreclosure mitigation. While there is some overlap with the GAO mission, it appeared the GAO was charged with ensuring compliance with the law whereas COP was charged with the impact of the policy on the overall marketplace. Each of these four accountability bodies has played a role in shaping the performance indicators used to assess the TARP and the Office of Financial Stability.

\section{UK Treasury Bailout Plan}

On October 8, 2008, the British Prime Minister Gordon Brown announced a major bank rescue plan that became known as the Bank Recapitalisation Scheme (BRS). A week later, on October 13th, three of the five largest UK banks were bailed out by the UK government for a total of 62.5 billion pounds. These institutions included the Royal Bank of Scotland, Lloyds and HBOS. This plan differed initially from the focus in the U.S. plan because it was specially designed to directly inject capital into troubled banks as opposed to purchasing troubled assets off the bank's balance sheets. The UK government began by pumping 30 billion pounds into the Royal Bank of Scotland. In January of 2009, the government was forced to nearly completely takeover this same bank and up its stake to over 70 percent. Taking a somewhat more hardline approach, in agreeing to buy up the bank, the UK government announced that the bank had agreed to an extension of lending commitments to large 
business customers as well as additional lending capacity to the tune of 6 billion pounds over the course of 2009. Also significantly different from the US approach, the RBS senior management team was expelled and a new management was put in place.

As part of the UK plan, banks were required to sign contracts with several important provisions. One provision was that there lending levels must return to the calendar year 2007 level for businesses and households. A second provision was that the government had a right to reject bank board of director positions and senior management and that government would be given preferred shares of stock in the bank. Also under the terms of the agreement, banks had a strong incentive to hold a strong cash position to repay the government's capital injection as quickly as possible. This last provision had some parliamentarians upset stating that for example "They are making them do the wrong things-making them store up cash to repay the government---when what you want them to do is lending out to businesses" (Telegraph, 2009).

In the UK bank bailout situation, several policy expectations were expressed as conditions for receiving government funds. Among the most important of these conditions was the stipulation that banks return to the 2007 lending levels. Another condition was that banks had to address and create programs for home mortgage modifications and the reduction of foreclosures. Under the UK plan, the government has established an asset manager called the UK Financial Investments company. This company has under its purview the Royal Bank of Scotland (70\% government owned), Lloyds (43\% government owned), Bradford and Bingley and Northern Rock (both 100\% government owned). The British banking system is highly concentrated with the eight firms, the so called major British banking group (MBBG) accounting for $2 / 3$ of all British mortgage lending, half of consumer credit and $70 \%$ of credit card debt access. These firms include Barclays, Lloyd's, HSBC, Abbey, Alliance and Leicester, Bradford \& Bingley, Northern Rock, and Royal Bank of Scotland. Of this group, the government has taken equity investments in Lloyds, RBS, Northern Rock and Bradford and Bingley.

The UK Treasury plan did not include any explicit language regarding new accountability or performance indictor mechanisms. It was unclear who or what would be responsible for ensuring the oversight of the expenditure of the funds and the compliance with the law by the banking institutions. Clearly, the House of Commons Treasury Select committee will have oversight authority into these ban recapitalization funds. It was unclear beyond this arrangement as to whether other bodies would be involved in some form of an accountability regime for the UK bank bailout. However, the lending level limit could be seen as the most important and clearly spelled out performance indicator. 


\section{Case Study Evidence and Analysis}

The case studies of the US and UK bank bailout will be analyzed in the following section. These cases will serve to motivate the framework depicted in section two. Each case will be analyzed one at a time followed by a comparative analysis of both cases. The first section will analyze the traditional annual performance reporting and indicator systems in the two countries. This will be followed by an assessment of the performance mechanisms used in the bank bailout systems. This information will then be brought together to assess the potential impact of the bank bailout performance indicators on the traditional, long performance planning and assessment at the UK and US Treasuries.

\section{U.S. Treasury Performance Management and the Bank Bailout: Case Study}

The US treasury has been engaged in performance management since at least 1993 . Under the Government Performance and Results Act of 1993 (GPRA) and under the Bush Administration Performance Assessment Rating System (PART), the department has maintained a strategic plan and a set of performance measures. In the US Treasury, the Office of Performance Budgeting and Strategic Planning is the key player in developing these systems for the department. The department's last strategic plan covered the five years for the period 2007 through 2012. This plan crosses two administrations and the financial and economic crisis of 2008-2009 occurred right in the middle of the plan period.

Every year the office of Performance Budgeting and Strategic Planning provides a performance report tied directly to the departments five year strategic plan. The report is used to establish how well the Treasury department is performing relative to established goals and benchmarks. The latest report was available for federal fiscal year 2008 which covered up to September 30, 2008. In that report, under the goal of "US and World Economies Performing at Full Potential", the treasury noted several items with respect to the financial crisis. It noted that it had proposed legislation to address liquidity in financial markets (the Emergency Stabilization act would not pass until Oct. 3 2008), participated in finding solutions for failing non deposit institutions, established a guarantee program for money market funds and helped establish the HOPE NOW alliance to assist homeowners. It also noted in the report under this goal, that performance was trending sideways and that budget and costs were increasing for the department (US Treasury, 2009). 
Within the Treasury Department, several divisions or offices play an important role in financial stability performance measures. The Office of Thrift Supervision (OTS) and the Office of the Comptroller of the Currency (OCC) are both key bank regulators who play a role in understanding potential volatility and risk within the bank supervision system. The OTS regulates federally chartered savings associations. According to the Office of Management and Budget (OMB), the OTS had established several key performance indicators related to 1 ) adequate capitalization and 2) containment of the regulatory burden on savings associations. The $\mathrm{OMB}$ also felt that the budget was aligned to program priorities and that any deficiencies were being addressed in the PART report. However, OMB had not graded or assessed the OTS since 2002. In that year, OTS received an effective grade in the PART system. Yet, 2008 was one of the biggest years for bank failures since the 1980 's savings and Loan Crisis. OTS regulated savings associations represented the greatest number of failures of all regulators. This raises the obvious question of the effectiveness and timeliness of the PART grading system and the overall OTS performance management system.

These same timeliness problems arose in terms of the national bank supervision program (Office of the Comptroller of the Currency) in treasury. This office oversees 54\% of the nation's banking assets and over 2,200 banks. This program area was also assessed by the PART system in 2002 and not since again. In 2002, the program was rated effective through the PART system. The office has several performance measures related to the prevention and mitigation of financial crisis. The Office of the Comptroller of the Currency (OCC) had established three performance measures including: 1) percent of national banks with composite CAMEL ratings of 1 or 2, 2) percentage of national banks that are categorized as well capitalized. These two measures directly relate to the financial crisis. It was the very health of the banking system that was thrown into question in the fall of 2008 . Yet, according to the OCC performance measures, the banking system was healthy and the OCC had met its target. In the case of measure one, the target was 95 percent of banks having CAMEL ratings of 1 or 2 and over 99 percent actually did. CAMEL ratings are based on OCC bank examiners assessments and are reviewed on a quarterly or semi-annual basis. The first measure, the CAMEL measure, is based on the bank regulators reports and records of a given bank. The CAMEL measure is countable, repeatable over time and uses a consistent methodology which strengthens its claim as a valid measure. This is a positive sign concerning the validity of such a measure. At the same time, while bank examiners receive extensive training, questions can be raised if all bank examiners are able to score the CAMEL system in the same manner. This could be a threat to data validity. 
In terms of legitimacy and functionality, these measures are widely accepted in the international financial community as being fair and effective ways to assess bank stability. There has been very little or no input from consumer or citizen based groups in terms of the CAMEL system. The functionality or usefulness of the CAMEL system seems to be in question when it failed to predict the 2008-2009 financial crises. So, while the measure may be valid and even accepted widely in the banking and regulatory community, there are important questions as to the effectiveness or usefulness of the measure, at least under extreme conditions as experienced in the fall of 2008. Bouckaert described this as a "technical and rhetoric system.... with technically valid and sound measures that are owned by those involved but which are not used properly" (Bouckaert, pg. 41, 1993). One possibility is that the CAMEL system itself was sound, but improperly implemented and used by banks and bank examiners either due to incompetence or part of a regulatory capture situation between banks and bank examiners. A second scenario is that the system is "symbolic" in that the banking community believes in the system but the measures are not valid or functional. A symbolic system is one where many of the major actors or stakeholders agree on and have been engaged in but does not work. In this case, the system failed to the extent that it harmed millions of individuals and brought down national economies; a high price to pay if in fact the system was symbolic.

The second measure regarding bank capitalization, based on self reporting, is also a countable and repeatable observation. At the same time, the self reported nature of the data may call into question some of the data. One factor that strengthens validity is that each bank's board of directors must certify the report in its submission. This places a level of due diligence on the bank board to ensure the accuracy of the data. This points to a mechanism by which national government agencies can ensure the validity of data submitted by outside entities, whether other governments or private companies.

In the case of the second measure, the OCC set a target of 95 percent and over 99 percent of banks actually achieved that categorization. In all of the years from 2001-2008, the CAMEL rating target was achieved by the OCC. The second measure is based on self reporting by banks concerning their perceptions of capitalization levels. Again, the target was easily achieved by the OCC throughout the 2000 's. This raises the question of are these the wrong measures or were these measures wrong. In one case, these may have simply been the wrong measures, either too broad or missed the mortgage toxic asset problem entirely. On the other hand, these measures may be misused or reported with erroneous 
information or data. In either case, this must call into question the performance management system as it is currently being used by the OCC and OTS in Treasury.

Thus far, this discussion has focused on the current performance management system for US Treasury. The research question poised here is the impact of the financial crisis on this system. To date, Treasury has not come full cycle in the process where the department strategic plan would be changed and adopted to reflect the changes in the economy. What is happening is that there is significant debate and turmoil over assessing the impact Treasury operations and management over the past eight months. There remain many questions as to the ultimate impact of the 2008 financial crisis on the long term structure and content of the US Treasury performance management system.

\section{Economic Stabilization Act and Redefining Performance}

The new accountability and performance mechanisms put in place by Congress in the fall of 2008 have shaken up, at least temporarily, the very notions of performance measurement and management in the US Treasury. Congress's operative theory being that the heavy oversight of these funds will ensure their proper usage. Given this high level of scrutiny, it remains clear that there is a significant degree of ambiguity over questions such as the amount of TARP funds spent and available at any given time, the impact these funds are having on the economy and finally the oversight of the funds usage in terms of items such as executive compensation and conflict of interest in the case of government contractors. There are also broader, long term questions that must be posed. What is the impact of performance indicators established for the TARP program and their consequences fro Treasury's overall performance management scheme?

This following section notes how performance indicators have been established for the Troubled Asset Relief Program, a bailout of these very same regulated banks, and the implications of the temporary performance systems and accountability measures on the long term structure of Treasury's overall performance management plan. The analysis is based on a review of the written reports and legislative testimony of the four political accountability bodies that are currently in place reviewing the TARP program. It should be noted that the four accountability bodies were as concerned with process issues as output or outcome measures of the policies enacted. Thus, reading the various reports, one finds evidence on the implementation of different rules such as executive compensation rules, processes for selecting TARP recipients, managing preferred stock and warrants and internal control issues and 
conflict of interest with contractors. These of course are all critical process issues that just be addressed especially in a government as large and complex as the United States government. However, the focus here is directed at outcome and output based performance indicators.

In December 2008, the first report on TARP was issued by the Government Accountability Office (GAO). The report noted several important deficiencies in the operations of the TARP program related to both process and overall performance of the program. The auditors noted that the department was struggling with the hiring process for the Office of Financial stability, internal controls related to contractors, protocols for addressing conflicts of interest and finally the overall impact of the program on financial stability. The report did note some progress that Treasury was making regarding process, output and outcome measures in relationship to the TARP programs. The Treasury had worked with GAO to establish some reporting requirements for TARP recipient banks in terms of loan balances, new loan originations by category and purchases of any type of asset backed security. These statistics were collected in part to determine if government funds were being used to continue or increase the flow of credit to consumers and businesses. Further, according to GAO, the Treasury had agreed to review quarterly call report data for all financial institutions receiving CPP funds. The GAO findings include the fact, that of the eight largest banks taking TARP funds, only one of those were separately tracking the use of the CPP funds. However, reviewing these reporting requirements, the deficiency in the accountability of tracking the impact of the CPP funds on consumer and business loans remained a critical gap according to GAO.

On January 30th 2009, the GAO issued its second report on the TARP. This report noted both some improvements along with some important continuing deficiencies. Partly in response to accountability and transparency concerns, Treasury had announced and it was reported by GAO that a new monthly lending report would be required from the largest TARP recipients. All other recipients would only be tracked via the quarterly bank call data available from the Federal Reserve. This appeared to be a compromise even as GAO noted that they would prefer to see more intense reporting from all TARP recipients. There was new criticism from GAO based on the fact that Treasury had not formulated or communicated an overall vision for how the TARP program was supposed to operate and improve the economy; it appeared generally to be an ad hoc strategy. In terms of internal control and hiring, GAO did report that Treasury had made progress in ensuring the control of conflicts of interest, better compliance with government contracts among recipients and continued hiring of key positions. 
Finally, GAO noted that some evidence pointed towards the stabilization of the credit market but that this remained an open question of the overall effectiveness of the TARP.

Finally, a third major GAO report was issued in March of 2009 (GAO, 2009). GAO noted that Treasury has made some improvements including better compliance management, better tracking of the use of funds by large institutions, better hiring practices and contracting oversight. On the other side, GAO still had cited that certain issues remain such as the fact that Treasury remains dependent on the banks for compliance information related to issues such as bonuses and dividend payment policy. Finally, while GAO noted some progress in Treasury defining the overall goals and objectives of the TARP, there remained important gaps in what exactly the strategy of the program is and how it will be tracked. To the extent that it is possible to track the impact of the program on the economy, the GAO reported that there are mixed signals in terms of improvements in the credit markets.

On February $5^{\text {th }}, 2009$, the Special Inspector General for the TARP program issued their first report (SIGTARP, 2009). According to the report, the US Treasury had established several key elements to implement the TARP program. One program was the Capital Purchase Program (CPP). As of the end of January 2009, 317 banks had received funds from the CPP. A second program was the Systemically Significant Failing Institution (SSFI) program which constituted the funds used for the bailout of the AIG Corporation. A third program consisted of the Targeted Investment Program (TIP) and Asset Guarantee Program (AGP) was a specific insurance type program used to stabilize Bank of America and Citigroup. As the Treasury switched from purchasing toxic assets to the direct injection of capital into banks, there was significant concern over the transparency and accountability for US investments. The SIGTARP most importantly wrote in their first report, "although there may be ways to model whether this theory is sound through macroeconomic metrics, it can be measured by examining what the banks actually did with the funds" (SIGTARP, Feb 6, 2009, pg. 94). This crucial statement summed up an important difference between the accountability bodies in defining and redefining performance. On the one side, many auditors and accountants felt that each dollar should be tracked while economists felt the only matter of concern were the big picture implications.

The second SIGTARP report was issued in late April, 2009. In this report, most importantly for the Capital Purchase Program (CPP), the SIGTARP noted that it was possible to receive full reporting from all TARP recipients regarding their use of the government funds. They strongly recommended, similar to GAO, that Treasury monitor the use of all government funds and not just the largest banks. Again, in this report, the SIGATRP harkened back to their first report and their concern with tracking the 
use of dollars as opposed to being involved in what they perceived to be relatively esoteric battles over macroeconomic metrics.

The third accountability body, the Congressional Oversight Panel (COP), has issued several monthly reports. In their first report, the COP directly addressed the issue of performance indicators (COP, Dec. 10, 2008). They noted for instance that GAO had proposed several performance indicators which they felt Treasury should take up and use such as the interbank lending rate, corporate spreads, call report data and mortgage foreclosures. The COP panel has written that they were concerned about Treasury's inability to track the use of dollars by the TARP recipients.

A month later, the COP introduced a second follow up report concerning accountability for TARP funds. Again, they demanded to ascertain the specific use of dollars by specific banks for transparency purposes. It was also unclear to as to the overall goals and mission of the treasury program which made it difficult to determine appropriate performance indicators. Again, the report indicated that "Treasury should set forth metrics by which success of the TARP..." (COP, January 9, 2009, pg. 9). The panel does give credit to Treasury for setting some metrics but points out weaknesses in these measures. For instance, in one case, it was unclear of the benchmarks or the timeframe for the measures being used related to market volatility. Finally, the panel notes that there are still no lending metrics for TARP recipients.

A third report, issued in April 2009, addressed the six month effects of the TARP program. In their assessment of the Treasury's measurement of performance, COP noted that some indicators had been put into place but understanding and interpreting those indicators was not a clear cut situation. On the one hand, it did appear that some reduction in risk in the credit markets had been achieved. At the same time, it was also clear that volati9vlty still remained and there was no clear cut sign of success yet. They agreed with Treasury that certain macroeconomic metrics had improved since fall 2008. However, they also wrote that some lending indicators were worsening and that access to credit was declining. Most importantly, the panel noted that "Treasury has yet to identify metrics by which they will measure the ultimate success of the programs.."(COP, April 2009, pg. 36).

At the end of April 2009, three of the accountability bodies, GAO, SIGTARP and COP, testified before the Senate Finance Committee. In prepared remarks, Neil Barofsky, Special Inspector General noted that the SIGTARP had taken action and asked and received from each TARP recipient a report on their use of government funds. He noted that this information would allow them to address the 
tracking of fund and that banks had reported using it for additional loan programs, capital cushions and repayment of lines of credit being called in by other financial institutions. Elizabeth Warren, the chairperson of the COP, remarked that her panel was still struggling with what were the strategic goals of the TARP and how they were to be tracked.

The fourth accountability body, the Financial Stability Oversight Board (FSOB), also released a report at the end of April 2009 (financialstability.gov, 2009). In a much more optimistic tone, the FSOB provided evidence, such as the narrowing of the London interbank offering rate, as evidence that the TARP program in fact is working. These positive statements are in contract to the more carefully nuanced evaluations of this same data as provided by GAO or COP in their own reports. The FOSB also spent considerable time in their report providing evidence that the loan or lending activity by banks had declined for a number of reasons including the reduction in consumer and business demand. Again, they appear to be at great pains to demonstrate the TARP has in fact worked in the sense that credit conditions would have been worse without the program. The FOSB also noted that Treasury is addressing internal control issues by creating two committees including the executive committee and the new program implementation team. It must be remarked that this report is far more favorable towards the TARP, including the capital purchase program (CPP) than the other three accountability bodies.

Other than the FOSB, all three other oversight bodies have noted that a major problem with regards to performance in TARP is the inability to track the use of the TARP funds and their impact on the overall financial stability of the economy and the protection of assets values. One crude measure of lending activity is the outstanding level of loan activity by TARP recipients. On January 26,2009 , the Wall Street Journal reported that of 13 the biggest TARP recipients, 10 saw a decline in their overall loan balance outstanding. The overall lending activity for the 13 banks fell from $\$ 3.36$ trillion to $\$ 3.31$ trillion in the fourth quarter of 2008. From a program evaluation standpoint, the relevant question is not whether loan balance has fallen; rather the question should be what the loan balance would have been in the absence of the TARP program, the so called counterfactual statement. This alternative evaluation question poses some significant methodological and data changes. It is very difficult to assess the activity of loan balance or lending activity in the absence of the TARP. This is partly due to the fact that in periods of economic decline, as the United states is currently experiencing, it would be expected that lending activity would likely fall. Therefore, the question may be has lending activity fallen less than it would have in the absence of the TARP. 
The COP, SIGTARP and GAO oversight bodies generally appear more interested in being able to separate out TARP funds from the banks existing funds. An audit trail would allow them to determine if the funds were used to pay large executive bonuses, simply be placed in the bank's loan loss reserves and build up capital reserves or be actively used in lending activity. Others have argued that this separate tracking of funds is misguided and misunderstands the basic problem facing the financial system (Bailey, 2009). Banking operates via leverage of its capital or deposit base. Generally, in normal times, one dollar of deposits or capital leads to $\$ 10$ dollars of lending activity. The general assumption is that the vast majority of these loans will be paid in a timely fashion with some accounting for loan loss reserves. However, beyond these fairly minimal normal defaults or delinquencies, major repayment problems can lead to a major constriction of banks capital reserve and its ability to provide further lending. If this becomes too severe, the bank may become insolvent. It was also true that the FOSB did not attempt to address the fund tracking accountability issue.

On February 17, 2009, in response both to the SIGTARP and GAO criticism regarding fund tracking, the US Department of Treasury released its first monthly bank lending survey via the Office of Financial Stability. This was at least in part due to the criticisms from the Government Accountability Office (GAO). Some important insights can be gleaned from the nature of the material in these reports. The first important point is that Treasury will only be surveying the top 20 recipients of TARP funding. One argument may be that accountability is not free; therefore prudence dictates that only the largest banks should be subject to constant oversight. Of course, while these banks have received the bulk of the funding, it does open the question as to the lack of answerability required by smaller banks and lenders. A second important point is that the banks themselves are allowed to respond in the report to the data detailing their current lending activity. In essence, this is certainly part of any performance indicator framework where there is justification or rationalization for bank activity to the government.

The following table represents some of the common statements or lack of statements regarding the justification or excuse making in terms of the banks use of the TARP funds. Several criteria were used to assess the banks own statements including: (1) documenting the change in lending from a previous quarter or year, (2) return on investment or payoff in terms of bank lending relative to TARP investment. These criteria were included because they give the reader a sense to which bank lending has changed relative to the past, an important indicator of the success of the program as well as the banks use of funds relative to the government's investment. 


\begin{tabular}{|c|c|c|}
\hline Bank & Loan Balance Comments & $\begin{array}{l}\text { Foreclosure Prevention } \\
\text { comments }\end{array}$ \\
\hline Bank of America & $\begin{array}{l}\text { Slight decline due to countrywide } \\
\text { acquisition and higher credit card risk } \\
\text { standards }\end{array}$ & $\begin{array}{l}230,000 \text { home loan } \\
\text { modifications }\end{array}$ \\
\hline Bank of New York Mellon ${ }^{2}$ & & $\begin{array}{l}\text { Purchase of US agency } \\
\text { securities }\end{array}$ \\
\hline BB\&T Corp. & $\begin{array}{l}5.3 \% \text { increase in year over year } \\
\text { lending due to decline in competition }\end{array}$ & No comments \\
\hline Capital One & $\begin{array}{l}\text { Slight decline in average loan balance } \\
\text { from } 2007 \text { due to poor economy }\end{array}$ & $\begin{array}{l}\text { Not a major player in } \\
\text { mortgages }\end{array}$ \\
\hline CIT Group & $\begin{array}{l}\text { Commercial loan activity down due } \\
\text { to poor economy from } 2007\end{array}$ & $\begin{array}{l}\text { Not a major player in } \\
\text { mortgages }\end{array}$ \\
\hline CitiGroup & $\begin{array}{l}\text { Comparison only to third quarter } \\
2008, \text { new consumer loan activity } \\
\text { down }\end{array}$ & $\begin{array}{l}\text { No comments, but a major } \\
\text { player }\end{array}$ \\
\hline Comerica & $\begin{array}{l}\text { Stated that while loan declines } \\
\text { occurred in } 4^{\text {th }} \text { quarter } 2008 \text {, smaller } \\
\text { decline that } 3^{\text {rd }} \text { quarter } 2008\end{array}$ & $\begin{array}{l}\text { No comment, some } \\
\text { mortgage activity noted }\end{array}$ \\
\hline Fifth Third & $\begin{array}{l}\text { Decline in new loan activity due to } \\
\text { seasonality and weaker demand, only } \\
\text { compared } 3^{\text {rd }} \text { and } 4^{\text {th }} \text { quarter } 2008\end{array}$ & $\begin{array}{l}\text { No comment, has a } \\
\text { mortgage business }\end{array}$ \\
\hline Goldman Sachs & $\begin{array}{l}\text { Major reduction in underwriting } \\
\text { business due to credit crisis, no } \\
\text { comparison to } 2007\end{array}$ & $\begin{array}{l}\text { Not a major mortgage } \\
\text { player }\end{array}$ \\
\hline
\end{tabular}

\footnotetext{
${ }^{2}$ Bank of New York Mellon is not a traditional commercial or consumer lender, but rather a provider of liquidity and financing to large institutional investors and banks
} 


\begin{tabular}{|c|c|c|}
\hline JP Morgan Chase & $\begin{array}{l}\text { Flat or no change in consumer } \\
\text { lending, no comparison to } 2007\end{array}$ & $\begin{array}{l}\text { Homeownership effort } \\
\text { expected to assist 400,000 } \\
\text { homeowners }\end{array}$ \\
\hline KeyCorp & $\begin{array}{l}\text { Loan balances trended lower due to } \\
\text { weaker demand and credit } \\
\text { tightening; no comparison to } 2007\end{array}$ & $\begin{array}{l}\text { No comment, but is a } \\
\text { mortgage player }\end{array}$ \\
\hline Marshall \& Ilsley & $\begin{array}{l}\text { Small gain in consumer lending, no } \\
\text { comparison to } 2007\end{array}$ & $\begin{array}{l}90 \text { day foreclosure } \\
\text { moratorium }\end{array}$ \\
\hline Morgan Stanley & $\begin{array}{l}\text { Major decline in underwriting } \\
\text { business and commercial loans } \\
\text { comprised to } 2007\end{array}$ & $\begin{array}{l}\text { Not a major mortgage } \\
\text { player }\end{array}$ \\
\hline Northern Trust & $\begin{array}{l}\text { Explicitly states that company } \\
\text { avoided subprime market; } 21 \% \\
\text { increase in consumer lending from } \\
2007\end{array}$ & $\begin{array}{l}\text { Established a } \\
\text { homeownership retention } \\
\text { program }\end{array}$ \\
\hline PNC Financial & $\begin{array}{l}\text { Consumer lending is down, no } \\
\text { explicit comparison to } 2007\end{array}$ & $\begin{array}{l}\text { Established Borrower } \\
\text { Outreach Team }\end{array}$ \\
\hline Region Financial & $\begin{array}{l}\text { Consumer lending down, no explicit } \\
\text { comparison to } 2007\end{array}$ & $\begin{array}{l}\text { Established a customer } \\
\text { assistance program }\end{array}$ \\
\hline State Street* & $\begin{array}{l}\text { Decline in activity due to poor } \\
\text { economy, no comparison to } 2007\end{array}$ & \\
\hline SunTrust & $\begin{array}{l}\text { Mortgage activity declined from } \\
\text { same period } 2007\end{array}$ & $\begin{array}{l}\text { No mention, but a } \\
\text { mortgage player }\end{array}$ \\
\hline U.S. Bancorp & $\begin{array}{l}\text { Consumer lending increased } 6.4 \% \\
\text { from } 3^{\text {rd }} \text { quarter } 2008 \text { to } 4^{\text {th }} \text { quarter; } \\
\text { no comparison to } 2007\end{array}$ & $\begin{array}{l}\text { No mention, but a major } \\
\text { mortgage player }\end{array}$ \\
\hline
\end{tabular}




\begin{tabular}{|l|l|l|}
\hline Wells Fargo & Extended $\$ 75$ billion in new credit & Established homeowner \\
& (noted a three to one match on TARP & assistance program to \\
investment); no comparison to 2007 & $\begin{array}{l}\text { assist 500,000 } \\
\text { homeowners }\end{array}$ \\
& & \\
\hline
\end{tabular}

The table illustrates several important elements of this part of the accountability and performance framework. Each bank responds in unique ways to the common questions posed by the US Treasury. Some banks, in particular Wells Fargo and Northern Trust, have explicitly chosen to state their aversion to state income loans, interest loans and other types of subprime mortgage market loans. This is likely to emphasize and signal to potential investors and regulators the banks soundness of decision making. Other banks, such as Citigroup, chose to avoid the question of their involvement in subprime or toxic assets and instead to focus on homeowner assistance programs in attempting to prevent "avoidable foreclosures". This was likely done to preempt congressional scrutiny and criticism of their use of TARP funds.

The Treasury did not explicitly ask the banks to prevent lending on a year over year basis but rather only for each month of the $4^{\text {th }}$ quarter of 2008. This is in contrast to the UK treasury approach which explicitly placed in the bank recapitalization contracts that lending must be maintained at the 2007 level. In some cases, banks such as Northern Trust explicitly provided additional information comparing their new and total lending activity between calendar year 2007 and 2008. Most other banks, following the Treasury guidelines, provided no explicit comparison to the lending activity of 2007. It is a valid question whether lending activity in 2007 is a fair or relevant comparison under the current economic circumstances. However, it does provide an additional benchmark from which a comparison of the credit contraction can be compared. The comparison of the three months in 2008 or even $3^{\text {rd }}$ versus $4^{\text {th }}$ quarter lending activity is fraught with seasonality challenges. Nevertheless, the performance framework question is the explicit choice of how bankers respond, or do not respond, to questions about lending activity. The answers to these questions by banks reveal much about their willingness to fully inform versus provide cover for their activities. It should be noted that GAO, in one of its monthly reports to congress, noted this problem of the appropriate relative comparison for lending activity to assess the success or failure of the TARP program. 
The performance framework also involves the types of questions, the timeliness and the format upon which Treasury constructs its system. This part of the regime is subject to the oversight by the three bodies appointed or directed by congress including SIGTARP, GAO and the COP. There has been a continual back and forth between these bodies which has reshaped the accountability regime. In this case study, the Treasury's Office of Financial Stability (OFS) has been very flexible and adaptive to changes in the accountability regime. These changes included, perhaps most importantly, was the new snapshot report which allowed Treasury to begin to address the impact of TARP investments on lending activity. The timeliness of this snapshot reporting has been adjusted to a monthly basis which is more frequent than the current bank "call reports" that are reported to the U.S. Federal Reserve on a quarterly basis regarding lending activity.

Treasury's bailout and emergency fund programs have been severely tested in a performance measurement context. The accountability bodies have been highly critical of a basic lack of any real framework to assess and track performance over time. The current system could be said to be lacking validity, legitimacy and functionality from many perspectives. There is a general lack of established indicators for performance, very few stakeholder groups buy into whatever system $\mathrm{f}$ indicators does exist and given the lack of system it is unlikely that any functionality or benefits can be derived. This is contrast to the current Treasury system that is considered by many to be an effective and strong performance system. Yet, this was the system that failed to capture the biggest financial crisis since the Great Depression. Thus, a larger question is the long run impact of the assessment of the TARP program on the Treasury's goals, objectives and performance indicators in the departments required strategic plan and performance reporting. The impact of the financial crisis will be long lived. It would certainly seem that such a crisis would have an impact on the more standard, routine performance indicators that the department would use well after the crisis. The long run question is how a system that is extremely timely and dealing with the immediate events of the day, yet lacking in some basic performance management characteristics influence or impact a stable, highly functioning performance management system over time?

\section{UK Performance Measurement System and Bank Bailout Impact}

In the UK budgeting system, every three years, a comprehensive spending review is conducted which sets budget limits by department as well as the types of improvements in services that citizens 
can expect. The comprehensive spending review identifies twenty or thirty Public Service Agreements (PSA) which are government wide with one department taking the lead although several departments may be involved. Each PSA is underpinned by a single delivery agreement which may cross cutting departments and service delivery agencies and a set of performance indicators to measure progress, success and failure. After the PSA's and delivery agreements are finished, each department establishes strategic objectives related to their specific tasks.

The UK treasury agreed to a be the lead agency on a number of public service agreements (PSA's) for itself in the FY 2007 budget process (UK Treasury, 2007). The original FY 2007 PSA's included elements around fairness and opportunity for all, a better quality of life, stronger communities and a more secure environment. In the FY 2009 budget, a new underpinning PSA, led by the UK Treasury, was added that was termed, "helping people and business through the downturn sooner and stronger". In essence, the government was making the case that its policy and interventions would alleviate the downturn conditions sooner and at a faster pace than if the marketplace had been left to its own whims.

The UK Treasury, as part of the Comprehensive Spending Review of FY 2007, also established several department al strategic objectives (DSO). One of the DSO's was entitled, "Ensuring high levels of economic growth, well being and prosperity for all." Under this DSO was a sub-objective which referred to "fair, stable and efficient financial markets". No specific performance measures were identified under this sub-objective, rather it was stated they would conduct a benchmarking exercise to compare UK financial market stability against international stability standards. Tied to this objective was another element related to financial regulation. The UK government has adopted a platform known as the "Better Regulation" scheme. The government's goal is multifaceted but includes several performance measurement targets. One target is to reduce administrative burden on companies as assessed through a 25 percent reduction in administrative costs by 2010. This goal would apply financial regulation and be taken up by the UK Treasury.

In the spring and fall of each year following the comprehensive spending review, the UK Treasury is required to provide regarding its actual performance relative to the standards, targets and indicators et in the departments strategic objectives document. In the December 2008 report, the Treasury updated its progress on performance. There were two items identified as "not assessed" in the fall performance report. The first item was the international benchmarking comparison of the UK banking system. The second indicator was an international comparison of the competiveness environment for financial services between the UK and the rest of the world. Again, one numeric target 
was specified as a 25 percent reduction in the administrative cost burden on financial services and banking firms.

In the UK's FY 2009 budget, which was submitted in the spring of 2009, a set of new national priorities had emerged. Chapter three of the budget is entitled financial stability. This chapter is noticeably absent from previous budgets. In fact, prior to FY 2009, the governments general national priorities, as expressed in the annual budget, had not altered over the past few years. It is noteworthy in the FY 2009, the UK government has laid out aggressive plans for making changes to the financial system but no evidence based measures were introduced in the budget. Thus, it appears that the government had not backed away or changed its publically stated indicators related to financial regulation in the comprehensive spending review and had not introduced new measures or indicators related to the national priority of financial stability. Given the early date, it is possible that such measures will be forthcoming.

Using Bouckaert and Halligans framework, the UK Treasury performance management system exhibited several characteristics. Unlike the US system, the UK system seemed somewhat deficient in terms of actual performance indicators. The system did have a clear set of goals and objectives which lended itself to a degree of validity but was lacking some of the various possible indicators. The one indicator it did possess was related to reducing the burden of red tape or administrative regulation on the financial sector. Certainly, The UK system did possess a degree of legitimacy in was considered by many as a leading example of advanced performance management. Finally, the system was functional in that the UK was considered to be a leading global finance center and reducing administrative burden and enhancing competitiveness would have been a very beneficial goal in general. However, it must also be stated, that in terms of other parts of the UK performance management system, the UK Treasury had a fairly weak and deficient system which lacked many performance indicators. Certainly, other countries, such as the USA, had identified potential measures and therefore the UK could have adopted or adapted from these systems. This lack of indicators is curious especially given the role of the UK Treasury in monitoring the overall government's performance management system. In Bouckaert's 1993 framework, the UK Treasury system would be described as a symbolic system. In this context, it is a system that stakeholders buy into, but lacks any real or valid measures and does not ultimately provide a great deal of widespread benefits. Given its strengths and weaknesses, this system would be tested and challenged as the events of the fall of 2008 unfolded. 


\section{UK Bank Bailout and Performance Redefined}

The UK Bank bailout was handled differently than in the US case. A third party, partially at arm's length from the central government, the United Kingdom Financial investments Corp. (UKFI) was created to handle the bailout funds and investments. Thus, questions of performance in the context of the bailout have to be addressed via this body which was directly reportable to the UK Treasury. A framework document was required to establish the relationship between the UK Treasury and the UK financial Investments Corporation as well as the relationship between the UKFI and the bank of which it owned stock. The main UKFI strategic challenge is the unwinding of the government's ownership of bank assets in a fashion that achieves the objectives as stated in the framework document. These objectives included: 1) UK Treasury should not be a permanent investor, 2) maintain financial stability, 3) promoting competition in the UK financial sector. The UKFI tactical approach was to maintain active engagement with the corporate boards it oversees, vote on corporate governance issues where appropriate and regularly report back to UK Treasury on progress and performance.

In a numeric or quantitative sense, it is difficult to assess the actual targets upon which UKFI should be evaluated. None of these types of targets are specified in the framework document which raises important questions. For example, will UKFI management seek to maximize taxpayer return or will it seek to maintain financial stability which may imply a much lower return for taxpayers. These questions were raised as the UKFI proposed selling convertible 3 year bonds as a form in which to disengage from its ownership positions of the financial institutions. These convertible bonds will provide a quick return on investment for the taxpayer. However, if at the end of three years, the bonds are not payable to the investor, the government and UKL Treasury could be forced to buy them back at great expense to the taxpayer. These same challenges face the US treasury as it will attempt to unwind its positions in US banks over time.

On May 1, 2009, the UK parliament issued a report which was highly critical of the UKFI structural arrangement and framework document with UK Treasury. The main complaint was that it was not independent enough of UK Treasury and would be therefore allow for government interference in the business of banking. This raises an accountability question. One structural mechanism would seem to be to form these organizations in a manner which prevented any conflict of interest or interference type problems to occur via the very nature of the organizational structure. In this case, ensuring that the UKFI was an independently run agency that would be at arm's length from Treasury. 
Another option would be the high level of ownership and control by UK Treasury via UKFI with a strong accountability and reporting element as a check and balance over ministerial authority.

According to the UKFI, the main metric by which they should be held accountable to was the return of the taxpayer's money in a timely fashion. Unlike in the US situation, possibly because of the limited number of institutions involved, the parliament did not question where the money was going or it was being used. The main questions centered on the role of the UK Treasury in running or managing the banking system vis-a-via the UKFI. The UK Treasury had stated a metric, in the contract with the bank bailout recipients, that lending would return to the CY 2007 levels. This type of metric was not given in the US bank bailout situation.

In a more macroeconomic context, the UK also has three key performance and accountability bodies have been tracking the overall economic situation with regard to the government's actions including the British Bankers Association, the UK Treasury Lending Panel and the Bank of England. One element of reporting and accountability was the UK Treasury's startup of a lending panel which is directly tied to the Bank of England. The panel was established with officials from UK Treasury, Bank of England and the Department for Business Enterprise. The goal of this panel was to determine was to determine credit access and cost to both consumers and businesses. Performance reporting for the Panel is via the Bank of England's monthly lending report (Bank of England, 2009). This report also does not break out lending for individual institutions. This lending report began in April of 2009. In the first report, it was noted that business lending had fallen significantly from 2008 levels. The report also notes that mortgage and remortgage lending has fallen to its lowest level since 1988. Unlike the US treasury reporting, the Bank of England has explicitly addressed the issue of trying to sort out whether lending is fallen due to demand reductions or supply constraints. This is critical to assessing the claims and justifications of the banking sector that it is a reduction in demand that is leading to a falloff in lending and is out of their control. The bank report also notes that tightening credit standards may be responsible for the falloff in demand rather than voluntary reductions by consumers. It has stated that it will rely on other reporting tools to ensure this is not the case. Again, the US Treasury has not attempted to provide a clear cut set of protocols for addressing these issues. The Bank of England report notes that the evidence is mixed regarding supply and demand factors in the credit situation. For example, with regards to mortgages, the report states that "it may be that part of the apparent weakness of mortgage demand perceived by lenders reflects constraints in loan supply" (Bank of England, pg. 13, 2009). 
The British Bankers Association, via their website, also provided some degree of accountability and performance reporting by reporting on overall bank lending (BBA, Feb 2009). It is important to note that they did not report on an individual bank basis but rather for the entire MBBG membership. This makes it impossible from this information to assess the degree of lending compliance by the banks that have taken part in the Bank Recapitalisation Scheme (BRS). They report that mortgage and remortgage lending was down over 30 percent from activity levels in February 2008. This was also true for consumer credit lending which was down 12 percent from the previous year and the same was true for business lending. Thus, it would appear that at least in aggregate, banks were not able to maintain lending levels at their 2007 previous highs. In the narrative of the report, the justification for these lower lending levels is that demand for credit has fallen with the recession.

The UK approach has relied on third parties to provide much of the data regarding bank activity and use of the bailout funds. In these cases, one nonprofit association, the British Bankers Association and in the second a government institution, the Bank of England has reported on lending activity. It cannot be denied that bank lending has actually fallen in the UK despite the government agreements with the bailout banks. At the same the rationale or justification for these lending declines appears to come with mixed signals as to whether banks can actually control such activity levels. This approach, with much of the accountability reporting coming from third parties, stands in contrast to the US approach. The US approach relies much more heavily on the reporting of lending activity by the financial institutions themselves. This allows for individual identification of the lending activity of any given firm.

In terms of accountability and performance, the UKFI is in a unique situation compared to the US bank bailout or even other countries. It is designed to be at arm's length from the UK government and UK Treasury in order that professional expertise and management will guide decision making rather than politics. The long term goal of the UKFI is to return tax payer money and ensure that the banking system remains in private hands (UKFI website, 2009). There is less debate or discussion in Britain regarding the overall level of lending, although banks have promised to maintain 2007 lending levels. Certainly, the level of scrutiny and transparent reporting in the US is absent in the UK plan. The UKFI has not been required at this time to provide extensive reporting on its own activities, internal controls or decisions it has made regarding the UK governments investments. A review of their website found only as publication regarding the framework document between the UK Treasury and the UKFI. 
The UK's emergency funds programs lack the degree of accountability bodies established in the United States. However, the system being developed to track performance of the UK bailout program may actually be more valid, legitimate and functional than the current UK Treasury traditional performance management system. Again, the question will what long run impact will this new, temporary set of indicators have on the long run functioning of the mainstream system. From the standpoint of the dynamics of a performance management system and performance regime, one of the key questions will be what changes are observed in the DSO's and indicators over time. Given the criticisms facing financial regulators and their role in the current economic crisis, a question must be raided as to whether these same benchmarking exercise and reductions in regulatory burden are the type of policy direction that will be followed particularly in the UK and US.

US and UK Bank Bailouts: A Comparative Performance Analysis

The UK and US bank bailout plans have engendered very different approaches to accountability and performance indicators. These different approaches, given the same type of policy program being implemented, may teach us something about the how performance management systems respond and change over time. What is evident to date, each country has embarked on adopting new performance indicators and accountability systems, on a parallel track, for the bailout funds while still currently maintaining their traditional performance management systems. The question becomes how will these tow systems interact and what will be the long term implications.

The US Treasury performance management system, nearly a decade and a half old, is based on a very logical based framework with goals, objectives and performance indicators. These different elements align very well in accordance with much of the literature on the performance measurement topic. Indicators such as bank capitalization and bank soundness in the CAMEL system were used by Treasury agencies such as the Office of the Comptroller of the Currency and Office of Thrift Supervision. These systems were given a strong evaluation by the Office of Management and Budget. Thus, this system, using the Bouckaert and Halligan framework for assessment, is valid and has a strong legitimacy factor among many stakeholders and is functional to a point. Despite all of these conditions, the U.S. banking system underwent a nearly cataclysmic failure second only to the Great Depression. How could such events occur if the performance management system was working? 
The UK Treasury performance management system was actually less developed and had fewer performance indicators present than the US Treasury performance system. The UK system appeared to be far more focused on determining actions that will reduce regulatory burdens. There were no specific measures related to bank capitalization for example. This is likely due to the heavy emphasis placed in the City of London to maintain and enhance the UK's global competiveness in the financial services industry. The UK experienced an equal if not greater collapse in its financial sector. The UK system was at least partially valid if perhaps incomplete, had strong legitimacy among government and industry and again was partially functional under normal economic conditions. However, the same questions raised in the U.S. system can be asked of the UK system. This is particularly crucial given the high regard given by many to the overall British government approach to performance management and governance.

In a comparative framework, the US and UK Treasuries present us with some interesting information. Given the failure of both performance management systems to capture the potential problems facing the financial industry, important questions about the efficacy of such systems must be raised. The two countries had very different approaches to performance measurement and financial regulation. Therefore, it would appear that larger and deeper problems exist within the structure of these governments. At a minimum, calls are needed for a complete examination of the performance management frameworks used in the two countries. To date, accountability bodies have focused on performance indicators for the emergency bank programs that now exist; however, little effort has been put forward to examine the long run performance management frameworks used by the two countries. Surely, this question must become more prevalent as the emergency situation begins to recede.

Another question that must be raised is the ability of two seemingly well constructed performance management systems too fail. Perhaps more attention must be paid to the potential of performance management systems to avoid catastrophic failure as opposed to simply managing the routine marginal questions of the day. The tow national Treasuries appeared to have well functioning performance management systems that met much of the criteria expected in the literature. Yet, at the end of the day they failed in very large and important ways. A new criterion for assessing performance indicators may be robustness to so called "black swan" events (Taleb, 2007). These are events that only occur on an infrequent basis but have a potentially massive impact on communities and society.

Related to the question of robustness to extreme events is the ability of performance management systems to garner real time relevant data to decision makers. Many systems are scaled for 
annual reporting. While useful in some context, this may be inappropriate for extreme event situations where real time information is required. Again, timeliness may be another criterion that needs to be added to the assessment toolbox.

\section{Conclusion}

The financial crisis that began in the spring of 2008 and exploded in 2009 has led to unprecedented government intervention in the financial services marketplace and across the entire spectrum of the economy. Enormous sums of money, totaling into the trillions of dollars and billions of pounds, is being expended in an effort to achieve financial stability, secure home ownership and many other goals and objectives, some better specified than others. In such an environment, public sector accountability for such funds and behavior takes on a new level of importance.

To date, the current public performance management literature has been more focused on snapshots and static understandings of such systems as opposed to their changes and evolution over time. The dynamics of performance management, which has been addressed for example by Christopher Pollitt, is an important gap in the knowledge base. This paper has attempted to begin to understand some of those dynamics. A major financial crisis presents an opportunity to examine both current and future performance management system changes and advance the state of knowledge.

The US and UK governments were well recognized for having advanced performance management frameworks. This is evident in the level of detail and careful linking of goals, objectives and performance indicators across the two systems. At the same time, these well functioning and well structured systems failed to prepare or assist decision makers in mitigating one of the biggest financial calamities in global history. This raises serious questions about the future and evolution of the current performance management frameworks employed by the US and UK Treasuries.

The current emergency financial efforts by the governments are being scrutinized and performance indicators are being debated and developed for these emergency funds. However, long run questions remain as to the impact of these temporary measures on the overall performance management frameworks of the two governments. Will robustness and timeliness playa more important role in future systems for example? Understanding these questions will advance the state of 
knowledge in the performance management filed concerning the dynamics of such systems over time and their responses to critical and extreme events.

Admittedly, this research is in the initial stages of understanding the changes in the two countries performance management systems. Over time, it will become clearer as to what long term changes will be put in place. However, the benefit of this research is to capture the initial movements and struggles over redefining and understanding the role and use of performance indicators in national Treasuries and financial regulation in light of the crisis. Future research efforts should focus on assessing changes in the UK and US Treasuries performance management systems as the financial crisis and emergency fades. Are long term changes evident in such systems? Also, interviews and field research could enhance secondary analysis of documents regarding the use, usefulness and changes in the performance frameworks. In the US context for example, there is a performance indicator financial regulator working group that could be a target for interviews and follow up work. 


\section{Bibliography}

Bank of England. Trends in Lending Report.

http://www.bankofengland.co.uk/publications/other/monetary/trendsinlending.htm

Bouckaert, G. (1993) “Measurement and Meaningful Management”, Public Productivity and Management Review, 17(1).

Bouckaert, G. and John Halligan. Managing Performance. Routledge, Oxford, England 2008.

British Bankers Association. http://www.bba.org.uk/bba/jsp/polopoly.jsp?d=145\&a=15571\&view=print . Accessed on March 12, 2009.

Congressional Oversight Panel. "TARP Oversight: A Six Month Update". March 31, 2009. http://cop.senate.gov/hearings/index.cfm

Congressional Oversight Panel. "Questions about the $\$ 700$ Billion Emergency Economic Stabilization Funds". Dec. 12th, 2008.http://cop.senate.gov/hearings/index.cfm

Financial Stability Oversight Board. "Quarterly Report to Congress" April 24th, 2009, www.financialstability.gov.

Financial Stability Oversight Board. "First Quarterly Report to Congress" December 31st, 2009, www.financialstability.gov.।

Government Accountability Office. "Additional Actions Needed to Ensure Integrity, Accountability and Transparency". GAO 09-266T December 10, 2008.

Government Accountability Office. "Status of Efforts to Address Transparency and accountability Issues". GAO 09-296, January 30, 2009.

Government Accountability Office. "Status of Efforts to Address Transparency and accountability Issues". GAO 09-504, March 31, 2009.

Pollitt, Christopher. Time, Policy and Management. Oxford University Press, Oxford, England, 2008.

Pollitt, Christopher. "Performance Indicators: A Logic of Escalation". European Group of public Administration Study Group II, Netherlands 2008, http://soc.kuleuven.be/io/egpa/qual/Rotterdam/Rotterdam\%20abstracts\%20and\%20papers.htm 
Pollitt, Christopher. "Performance Indicators in the Longer Term" Public Money and Management, Autumn 1989.

Special Inspector General of the Troubled Assets Relief Program. "Initial Report to the Congress". February 6, 2009, www.sigtarp.gov.

Special Inspector General of the Troubled Assets Relief Program. "Quarterly Report to the Congress". April 21, 2009 www.sigtarp.gov.

Talbot, Colin and Carole Johnson and Jay Wiggan. "Exploring Performance Regimes: A New Approach to Understanding Public sector Performance". Nottingham Policy Centre, University of Nottingham, June 2005.

Taleb, Nicholas Nassim. The Black Swan. Random House, New York, NY 2007.

United Kingdom Financial Investments. http://www.ukfi.gov.uk/. accessed on May 5, 2009.

United Kingdom Treasury. "Comprehensive Spending Review of FY 2007" . http://www.hmtreasury.gov.uk/pbr_csr07_index.htm

United States Treasury. "2008 Performance and Accountability Report". http://www.ustreas.gov/offices/management/dcfo/accountability-reports/2008-par.shtml 